\title{
ANALISIS KEMAMPUAN PEMECAHAN MASALAH MATEMATIK PADA MATERI KUBUS DAN BALOK BERBENTUK SOAL KONTEKSUAL DITINJAU DARI GENDER SISWA
}

\author{
Andos Sitohang \\ Universitas Katolik Santo Thomas, Medan; \\ andossitohang1995@gmail.com
}

\begin{abstract}
Abstrak. Penelitian ini bertujuan untuk mendeskripsikan kemampuan siswa dalam pemecahan masalah matematik pada materi kubus dan balok berbentuk soal kontekstual ditinjau dari gender siswa kelas VIII SMP Dharma Wanita Pertiwi Medan. Penelitian ini menggunakan metode deskriftif. Subjek penelitian ini adalah siswa kelas VIII yang terdiri dari 30 orang yang terdiri dari 19 siswa laki-laki dan 11 siswa perempuan. Objek penelitian ini adalah kemampuan siswa dalam pemecahan masalah pada materi kubus dan balok berbentuk soal kontekstual. Metode pengumpulan data berupa observasi, tes tertulis dan wawancara terkait kemampuan pemecahan masalah dengan menggunakam langkah penyelesaian george polya. Hasil penelitian ini menunjukkan siswa perempuan memiliki kemampuan memahami masalah, menyusun rencana penyelesaian, dan memeriksa kembali solusi yang lebih unggul dibandingkan laki-laki. Sedangkan untuk melakukan perhitungan siswa memiliki kemampuan yang sama antara laki-laki dan perempuan. Persentase kemampuan pemecahan masalah untuk laki-laki $16,6 \%$ dan perempuan $30 \%$ dilihat dari pengelompokan pemecahan masalah di atas rata-rata. Berdasarkan analisis data dapat disimpulkan bahwa siswa perempuan memiliki kemampuan pemecahan masalah yang lebih unggul dibandingkan siswa laki-laki.
\end{abstract}

Kata Kunci. Pemecahan masalah, gender, polya, kubus, balok.

Abstract. This study aims to describe the ability of students in solving
mathematical problems in the cube and beam-shaped contextual questions in
terms of the gender of eighth grade students of Medan Dharma Wanita Pertiwi
Medan. This research uses descriptive method. The subjects of this study were
students of class VIII consisting of 30 people consisting of 19 male students and
11 female students. The object of this research is the ability of students to solve
problems in cube and block material in the form of contextual questions.
Methods of data collection in the form of observation, written tests and

Cartesius: Jurnal Pendidikan Matematika Vol. 3, No. 1

CProdi Pendidikan Matematika Universitas Katolik Santo Thomas 
interviews related to the ability to solve problems using george polya's completion steps. The results of this study indicate that female students have the ability to understand problems, plan solutions, and re-examine solutions that are superior to men. Meanwhile, to do the calculations students have the same ability between men and women. The percentage of problem-solving skills for men $16.6 \%$ and $30 \%$ for women is seen from the above-average grouping of problem solving. Based on data analysis, it can be concluded that female students have superior problem solving abilities compared to male students.

This study aims to determine whether the application of the Problem Solving learning model can improve students' mathematical critical thinking skills. This type of research is Classroom Action Research (CAR). The subjects in this study were students of class VII SMP Yos Yoseph Medan, which consisted of 32 students. The object in this study is the Problem Solving learning model to improve students' critical thinking skills in solving mathematical problems. Based on the analysis of research data, the results obtained are: the initial test of mathematical critical thinking ability of students is still relatively low that is obtained a classical average of 49.84 , as many as 8 students who completed $25 \%$ with a percentage of $25 \%$ while students who did not complete as many as 24 people with $75 \%$ percentage. The results of the first cycle test after using the Problem Solving learning model obtained a classical average value of 63.90, 17 students completed with a percentage of $53.12 \%$, while students who did not complete as many as 15 people with a percentage of $46.87 \%$. In the second cycle after making improvements to the learning model Problem Solving obtained an increase in the classical average value of 75.78 students who completed 26 students with a percentage of $81.25 \%$ while students who did not complete as many as 6 people with a percentage of $18.75 \%$. So it can be concluded that the Problem Solving learning model that has been applied can improve students' mathematical critical thinking skills. This is supported by the data obtained by the average classical completeness of students' mathematical critical thinking skills obtained by the Problem Solving learning model in cycle II higher than cycle I.

Keywords. Problem solving, gender, polya, cube, beam.

\section{PENDAHULUAN}

Matematika merupakan salah satu mata pelajaran yang memiliki peranan penting dalam dunia pendidikan sehingga wajib diajarkan di setiap jenjang pendidikan, dimulai dari SD, SMP, SMA dan bahkan di Perguruan Tinggi. Namun, kedudukan matematika dalam kehidupan yang strategis berbanding terbalik dengan tanggapan negatif siswa terhadap matematika.

Cartesius: Jurnal Pendidikan Matematika Vol. 3, No. 1

CProdi Pendidikan Matematika Universitas Katolik Santo Thomas 
Tidak sedikit siswa yang beranggapan bahwa matematika merupakan pelajaran yang sulit untuk dipahami, pelajaran yang membosankan bahkan menjadi pelajaran yang ditakuti. Sriyanto (dalam Saragih, dkk., 2013: 196) menyatakan bahwa sebagian besar siswa menganggap matematika sebagai suatu pelajaran yang menakutkan dan cendrung dianggap pelajaran yang sulit. Meskipun sulit, matematika sangat penting jika dilihat dari manfaat dan kegunaan dalam kehidupan sehari-hari dan dapat disimpulkan bahwa matematika secara tidak langsung sangat mempengaruhi kehidupan setiap orang di masa yang akan datang.

Walaupun matematika memiliki peran yang penting dalam penentuan masa depan seseorang, tetapi dari hasil study literatur yang dibaca peneliti diketahui bahwa kemampuan bermatematika siswa masih tergolong rendah. Ada banyak faktor yang menyebabkan rendahnya kemampuan matematika siswa, salah satunya adalah kemampuan pemecahan masalah matematik siswa yang masih rendah. Kemampuan pemecahan masalah matematika ini memudahkan siswa dalam penyelesaian soal matematika.

Menurut Susanto (2014: 194) pemecahan masalah merupakan komponen yang sangat penting dalam matematika untuk menerapkan pengetahuan (knowledge) yang telah diperoleh siswa sebelumnya ke dalam situasi yang baru. Dalam pemecahan masalah ini juga termasuk salah satu aktivitas yang sangat penting dalam pembelajaran matematika, karena tujuan belajar yang ingin dicapai dalam pemecahan masalah berkaitan dengan kehidupan sehari-hari.

Proses pemecahan masalah matematik merupakan salah satu kemampuan dasar matematik yang harus dikuasai siswa sekolah menengah. Pentingnya pemilikan kemampuan tersebut tercermin dari pernyataan Branca (Hendriana, dkk., 2014: 23) bahwa pemecahan masalah matematika merupakan salah satu tujuan penting dalam pembelajaran matematika bahkan proses pemecahan masalah matematik merupakan jantungnya matematika. Pendapat tersebut sejalan dengan tujuan pembelajaran matematika, tujuan tersebut antara lain: menyelesaikan masalah,

Cartesius: Jurnal Pendidikan Matematika Vol. 3, No. 1

CProdi Pendidikan Matematika Universitas Katolik Santo Thomas 
berkomunikasi dalam simbol matematik, tebel, diagram, dan lainnya; menghargai kegunaan matematika dalam kehidupan sehari-hari, memiliki rasa tahu, perhatian, minat belajar matematika, serta memiliki sikap teliti dan konsep diri dalam menyelesaikan masalah.

Pentingnya kemampuan pemecahan masalah oleh siswa dalam matematika juga ditegaskan oleh Branca (Farichah, dkk., 2018: 2), yaitu:

1. Kemampuan menyelesaikan masalah merupakan tujuan umum pengajaran matematika,

2. Pemecahan masalah yang meliputi metode, prosedur, dan strategi merupakan inti dan utama dalam kurikulum matematika,

3. Pemecahan masalah merupakan kemampuan dasar dalam belajar matematika.

Oleh karena itu dengan mengacu dari pendapat ahli tersebut, maka pada pembelajaran matematika sangatlah penting bagi siswa untuk menguasai dan mengembangkan kemampuan pemecahan masalah matematika. Pada proses pembelajaran matematika, salah satu bentuk permasalahan atau soal yang dapat diberikan guru dalam menganalisis hasil pekerjaan siswa berkaitan dengan kemampuan pemecahan masalah adalah soal berbentuk kontekstual. Hal ini dikarenakan, dalam pemecahan masalah berbentuk soal kontekstual siswa dituntut untuk berusaha sendiri mencari solusi dengan menentukan perencanaan dan berbagai strategi penyelesaian yang di kuasainya. Hal ini tidak terlepas dari konsep matematika serta pengetahuan lain yang dibutuhkan dalam pemecahan masalah tersebut. Selain itu, siswa juga di harapkan untuk menyajikan proses atau aktivitas apa saja yang di gunakan untuk menyelesaikan soal berbentuk kontekstual.

Pada kenyataannya masalah yang terjadi kreativitas siswa dalam memecahkan masalah masih tergolong rendah. Hal tersebut juga berpengaruh terhadap gender, Dwi Narwoko (Widiawati, dkk., 2011: 6) menjelaskan gender adalah suatu istilah yang di gunakan untuk menggambarkan perbedaan antara laki-laki dan perempuan secara sosial yang tampak apabila dilihat dari nilai dan tingkah laku. Tingkat kedispilinan

Cartesius: Jurnal Pendidikan Matematika Vol. 3, No. 1

CProdi Pendidikan Matematika Universitas Katolik Santo Thomas 
antara siswa laki-laki dan siswa perempuan juga berbeda, perbedaan keaktifan di kelas antara siswa laki-laki dan siswa perempuan yang berdampak pada hasil belajar matematika. Namun hal ini belum terlalu diperhatikan baik oleh guru maupun sekolah. Pada dasarnya, perbedaan gender tidak hanya berkaitan dengan masalah biologis tetapi juga berkaitan dengan kemampuan yang dimiliki oleh laki-laki dan perempuan. Krutetski (Nafi'an, dkk., 2011: 573) menjelaskan perbedaan antara laki-laki dan perempuan dalam belajar matematika sebagai berikut:

1. Laki-laki lebih unggul dalam penalaran, perempuan lebih unggul dalam ketepatan, ketelitian, kecermatan, dan keseksamaan berpikir.

2. Laki-laki memiliki kemampuan matematika dan mekanika yang lebih baik daripada perempuan, perbedaan ini tidak nyata pada tingkat sekolah dasar akan tetapi menjadi lebih jelas pada tingkat yang lebih tinggi.

Berdasarkan hasil observasi di SMP Dharma Wanita Pertiwi Medan peneliti memperoleh informasi dari bapak Bukhori S.Pd mengenai kemampuan pemecahan masalah, diantaranya ketika guru berada didalam ruangan kelas dan memberikan soal-soal yang berkaitan dengan pembelajaran, hanya sebagian siswa yang antusias dalam mencari solusi terhadap masalah tersebut. Hal ini biasanya dilakukan siswa yang duduk didepan kelas. Selain itu, siswa yang duduk didepan kelas biasanya siswa perempuan, sehingga ada kecendrungan siswa perempuan yang lebih aktif mengerjakan ataupun menjawab soal-soal yang diberikan guru. Walaupun demikian, hal-hal yang berkaitan dengan gender tersebut dianggap sebagai hal yang biasa yang terjadi disekolah sehingga kurang diperhatikan oleh guru.

Selain data tersebut, berdasarkan hasil wawancara dengan guru pengampu mata pelajaran di SMP Dharma Wanita Pertiwi Medan menunjukkan bahwa kemampuan siswa dalam menyelesaikan masalah belum sepenuhnya baik. Hal ini terlihat ketika siswa menjawab soal mengenai kubus dan balok masih memiliki kesulitan, terlebih ketika dihadapkan dengan soal kontekstual yang membutuhkan pemikiran dan srategi yang tidak sederhana. Oleh karena itu, guru masih harus ekstra dalam mendampingi siswa agar siswa dapat

Cartesius: Jurnal Pendidikan Matematika Vol. 3, No. 1

CProdi Pendidikan Matematika Universitas Katolik Santo Thomas 
berpikir kritis dalam menentukan langkah awal penyelesaian. Idealnya permasalahan atau soal yang baik diberikan kepada siswa untuk mengukur tingkat kemampuan siswa dalam pemecahan masalah adalah soal kontekstual (cerita).

Peneliti mengambil materi kubus dan balok, karena pada mata pelajaran matematika khususnya materi kubus dan balok tidak lepas dari masalah matematika yang berkaitan dengan kehidupan sehari-hari salah satu contohnya mengetahui luas sebuah luas ruangan kelas dan papan tulis yang ada dalam ruangan kelas siswa. Berdasarkan uraian diatas, maka peneliti akan melakukan penelitian yang berjudul "Analisis Kemampuan Pemecahan Masalah Matematik pada Materi Kubus dan Balok Berbentuk Soal Kontekstual Ditinjau dari Gender Siswa Kelas VIII SMP Dharma Wanita Pertiwi Medan Tahun Pelajaran 2018/2019".

\section{METODE}

Jenis penelitian yang dilakukan dalam penelitian ini adalah penelitian deskriptif. Menurut Best, penelitian deskriptif merupakan metode penelitian yang berusaha menggambarkan dan menginterpretasikan objek sesuai dengan apa adanya (Sukardi, 2013: 157). Dalam penelitian ini Pendekatan penelitian dilakukan dengan pendekatan campuran kuantitatif dan kualitatif. Data kuantitatif diperoleh dari observasi aktivitas siswa dan tes tertulis. Data kualitatif diperoleh dari tes tertulis dan wawancara terkait konfirmasi ulang proses pengerjaan tes tertulis untuk mengetahui cara atau pola berpikir mengenai kemampuan pemecahan masalah.Data tes tertulis, terbagi menjadi data kuantitatif dan data kualitatif. Data kuantitatif disajikan dalam bentuk uraian naratif dari hasil pengerjaan tes tertulis dari subjek penelitian. Penelitian ini dilaksanakan di SMP Dharma Wanita Pertiwi, yang beralamat di Jln. Melati II No 30 Komp. Pemda Medan, semester ganjil tahun Pelajaran 2018/2019.

Adapun subjek penelitian ini adalah siswa kelas VIII yang terdiri dari 30 orang yang diantaranya laki-laki berjumlah 19 orang dan perempuan berjumlah 11 orang. Pemilihan kelas VIII A sebagai kelas penelitian bukan

Cartesius: Jurnal Pendidikan Matematika Vol. 3, No. 1

CProdi Pendidikan Matematika Universitas Katolik Santo Thomas 
didasari oleh kriteria tertentu. Hal ini dikarenakan tingkat prestasi belajar yang dimiliki kelas VIII di SMP Dharma Wanita Pertiwi Medan hampir sama. Oleh karena itu, kelas manapun yang terpilih sebagai subjek penelitian akan mendapatkan hasil yang tidak jauh berbeda dengan kelas-kelas lain yang tidak terpilih sebagai subjek penelitian.

Metode pengumpulan data adalah salah satu cara yang digunakan peneliti untuk mendapatkan data yang diperlukan dalam penelitian. Karena tujuan utama peneliti adalah mendapatkan data. Adapun metode pengumpulan data yang digunakan dalam penelitian ini adalah observasi, tes tertulis, dan wawancara.

Tabel 1. Kisi-Kisi Lembar Observasi Aktivitas Siswa

\begin{tabular}{|c|c|}
\hline $\begin{array}{c}\text { Indikator } \\
\text { Pemecahan Masalah }\end{array}$ & Aspek yang Diamati \\
\hline \multirow{3}{*}{ Memahami masalah } & $\begin{array}{l}\text { Siswa mampu menuliskan unsur-unsur yang } \\
\text { diketahui dari soal kontekstual yang diberikan }\end{array}$ \\
\hline & $\begin{array}{l}\text { Siswa mampu menuliskan unsur-unsur yang } \\
\text { siketahui dari soal kontekstual yang diberikan }\end{array}$ \\
\hline & $\begin{array}{l}\text { Siswa bertanya kepada guru atau teman jika ada } \\
\text { soal kontekstual yang kurang jelas }\end{array}$ \\
\hline \multirow{4}{*}{$\begin{array}{l}\text { Menyusun } \\
\text { rancangan } \\
\text { pemecahan masalah }\end{array}$} & $\begin{array}{l}\text { Siswa mampu menemukan rumus-rumus yang } \\
\text { diperlukan dalam penyeelasian soal kontekstual }\end{array}$ \\
\hline & $\begin{array}{l}\text { Siswa bertanya kepada guru jika kesulitan } \\
\text { menemukan rumus-rumus yang diperlukan dalam } \\
\text { penyeelasian soal kontekstual }\end{array}$ \\
\hline & $\begin{array}{l}\text { Siswa menyampaikan pendapat manapun ide } \\
\text { yang dimiliki untuk menjawab pertanyaan } \\
\text { mengenai apa saja rumus yang dipergunakan } \\
\text { dalam penyelesaian soal kontekstual }\end{array}$ \\
\hline & $\begin{array}{l}\text { Siswa berdiskusi bersama teman jika kesulitan } \\
\text { menemukan rumus-rumus yang diperlukan dalam } \\
\text { penyelesaian soal kontekstual }\end{array}$ \\
\hline Melakukan & Siswa mampu menerapkan rumus-rumus yang \\
\hline
\end{tabular}

Cartesius: Jurnal Pendidikan Matematika Vol. 3, No. 1

CProdi Pendidikan Matematika Universitas Katolik Santo Thomas 


\begin{tabular}{|c|c|c|}
\hline \multirow{4}{*}{\multicolumn{2}{|c|}{ perhitungan }} & diperlukan dalam penyeelasian soal kontekstual \\
\hline & & Siswa aktif melakukan perhitungan dalam \\
\hline & & penyelesaian soal kontekstual \\
\hline & & $\begin{array}{l}\text { Siswa menampaikan pendapat maupun ide } \\
\text { kepada teman yang mengalami kesulitan saat } \\
\text { melakukan perhitungan dalam penyelesaian soal } \\
\text { kontekstual }\end{array}$ \\
\hline \multirow{4}{*}{$\begin{array}{l}\text { Memeriksa } \\
\text { solusi }\end{array}$} & \multirow{4}{*}{ kembali } & $\begin{array}{l}\text { Siswa mengaitkan kembali solusi yang diperoleh } \\
\text { dengan apa yang ditanyakan pada soal } \\
\text { kontekstual }\end{array}$ \\
\hline & & $\begin{array}{l}\text { Siswa menjelaskan hasil pekerjaanya di depan } \\
\text { kelas }\end{array}$ \\
\hline & & $\begin{array}{l}\text { Siswa memberikan sanggahan kepada hasil } \\
\text { pekerjaan teman di kelas }\end{array}$ \\
\hline & & $\begin{array}{l}\text { Siswa menjelaskan cara lain yang digunakan } \\
\text { untuk mendapatkan solusi dari soal kontekstual } \\
\text { yang diberikan }\end{array}$ \\
\hline
\end{tabular}

Terkait wawancara yang dilaksanakan pada penelitian ini maka disusunlah kisi-kisi pedoman wawancara yang disajikan pada tabel berikut:

Tabel 2. Kisi-Kisi Pedoman Wawancara

\begin{tabular}{ll}
\multicolumn{1}{c}{$\begin{array}{c}\text { Indikator Pemecahan } \\
\text { Masalah }\end{array}$} & \multicolumn{1}{c}{ Pertanyaan } \\
\hline Memahami masalah & $\begin{array}{l}\text { Apa saja yang diketahui soal cerita } \\
\text { tersebut? Coba jelaskan }\end{array}$ \\
\cline { 2 - 2 } & $\begin{array}{l}\text { Apa saja yang ditanyakan dari soal } \\
\text { cerita tersebut? Coba jelaskan }\end{array}$ \\
& $\begin{array}{l}\text { Apakah kamu menemukan kesulitan } \\
\text { dalam memahami unsur-unsur yang } \\
\text { diketahui dan ditanyakan sari soal } \\
\text { cerita tersebut? Coba jelaskan! }\end{array}$ \\
\hline Menyusun rancangan & Mengapa kamu memilih cara atau \\
\hline
\end{tabular}

Cartesius: Jurnal Pendidikan Matematika Vol. 3, No. 1

CProdi Pendidikan Matematika Universitas Katolik Santo Thomas 


\begin{tabular}{ll}
\hline pemecahan masalah & \multicolumn{2}{l}{ rumusan tersebut? } \\
\cline { 2 - 3 } Melakukan perhitungan & $\begin{array}{l}\text { Menurutmu apakah langkah } \\
\text { penyelesaian atau perhitugan yang } \\
\text { kamu lakukan sudah tepat? Coba }\end{array}$ \\
& jelaskan \\
\hline Memeriksa kembali solusi & Apakah kau mengecek kembali solusi \\
& yang telah kamu peroleh? Bagaimana \\
& kamu mengeceknya? \\
& Dapatkah kamu memperoleh solusi \\
& tersebut dengan cara lain? Coba \\
& jelaskan! \\
\hline
\end{tabular}

Pedoman penilaian tes kemampuan pemecahan masalah yang digunakan dalam menganalisis hasil jawaban siswa disajikan pada tabel berikut:

Tabel 3. Pedoman Penilaian Tes Kemampuan Pemecahan Masalah

\begin{tabular}{|c|c|c|}
\hline $\begin{array}{c}\text { Tahap } \\
\text { Pemecahan } \\
\text { Masalah }\end{array}$ & Skor & Kriteria \\
\hline \multirow{4}{*}{$\begin{array}{l}\text { Memahami } \\
\text { masalah }\end{array}$} & 0 & $\begin{array}{l}\text { Tidak dapat menafsirkan informasi soal dengan } \\
\text { menuliskan unsur-unsur yang diketahui dan } \\
\text { ditanyakan }\end{array}$ \\
\hline & 1 & $\begin{array}{l}\text { Mampu menafsirkan sebagian informasi dari } \\
\text { soal. Dalam artian hanya dapat menuliskan } \\
\text { unsur-unsur yang diketahui tanpa menuliskan } \\
\text { unsur-unsur yang ditanyakan atau sebaliknya. }\end{array}$ \\
\hline & 2 & $\begin{array}{l}\text { Mampu menafsirkan informasi dari soal dengan } \\
\text { menuliskan unsur-unsur yang diketahui dan } \\
\text { ditanyakan namun kurang lengkap }\end{array}$ \\
\hline & 3 & $\begin{array}{l}\text { Mampu menafsirkan seluruh informasi dari soal } \\
\text { dengan menuliskan unsur-unsur yang diketahui } \\
\text { dan ditanyakan secara tepat }\end{array}$ \\
\hline $\begin{array}{l}\text { Membuat } \\
\text { rancangan }\end{array}$ & 0 & $\begin{array}{l}\text { Tidak dapat menuliskan rumus-rumus yang } \\
\text { diperlukan }\end{array}$ \\
\hline
\end{tabular}

Cartesius: Jurnal Pendidikan Matematika Vol. 3, No. 1

CProdi Pendidikan Matematika Universitas Katolik Santo Thomas 


\begin{tabular}{|c|c|c|}
\hline \multirow[t]{3}{*}{$\begin{array}{l}\text { pemecahan } \\
\text { masalah }\end{array}$} & 1 & $\begin{array}{l}\text { Menuliskan seluruh rumus yang diperlukan } \\
\text { secara tidak rinci sehingga tidak sesuai dengan } \\
\text { prosedur yang benar }\end{array}$ \\
\hline & 2 & $\begin{array}{l}\text { Menuliskan sebagian rumus yang diperlukan } \\
\text { secara tidak rinci sehingga tidak sesuai dengan } \\
\text { prosedur yang benar }\end{array}$ \\
\hline & 3 & $\begin{array}{l}\text { Menuliskan seluruh rumus yang diperlukan } \\
\text { secara rinci sehingga sesuai dengan prosedur } \\
\text { yang benar }\end{array}$ \\
\hline \multirow{4}{*}{$\begin{array}{l}\text { Melakukan } \\
\text { perhitungan }\end{array}$} & 0 & Tidak melakukan perhitungan sama sekali \\
\hline & 1 & $\begin{array}{l}\text { Melakukan seluruh } \quad \text { langkah-langkah } \\
\text { perhitungan yang tidak sesuai prosedur }\end{array}$ \\
\hline & 2 & $\begin{array}{l}\text { Melakukan sebagian langkah-langkah } \\
\text { perhitungan yang tidak sesuai prosedur }\end{array}$ \\
\hline & 3 & $\begin{array}{l}\text { Melakukan seluruh langkah-langkah } \\
\text { perhitungan sesuai dengan prosedur dan } \\
\text { menghasilkan jawaban yang benar }\end{array}$ \\
\hline \multirow{4}{*}{$\begin{array}{l}\text { Memeriksa atau } \\
\text { menafsirkan } \\
\text { kembali solusi }\end{array}$} & 0 & $\begin{array}{l}\text { Tidak mengaitkan kembali solusi yang diperoleh } \\
\text { dengan apa yang ditanya }\end{array}$ \\
\hline & 1 & $\begin{array}{l}\text { Mengaitkan kembali solusi yang diperoleh } \\
\text { dengan apa yang ditanya }\end{array}$ \\
\hline & 2 & $\begin{array}{l}\text { Mengaitkan kembali solusi yang diperoleh } \\
\text { dengan apa yang ditanyasecara tidak tepat }\end{array}$ \\
\hline & 3 & $\begin{array}{l}\text { Mengaitkan kembali solusi yang diperoleh } \\
\text { dengan apa yang ditanyasecara tepat }\end{array}$ \\
\hline \multicolumn{3}{|c|}{ Skor maksimal = jumlah soal $x$ skor maksimal per nomor } \\
\hline \multicolumn{3}{|c|}{$=5 \times 12$} \\
\hline \multicolumn{3}{|c|}{ Nilai akhir $=\frac{\text { skor perolehan }}{\text { skor maksimal }(60)} \times 100$} \\
\hline
\end{tabular}

Cartesius: Jurnal Pendidikan Matematika Vol. 3, No. 1

CProdi Pendidikan Matematika Universitas Katolik Santo Thomas 


\section{HASIL DAN PEMBAHASAN}

Penelitian dilaksanakan di SMP Dharma Wanita Pertiwi, yang berlokasi di Jl. Melati II No 30 Komp. Pemda Medan. Penelitian dilakukan di kelas VIII pada tanggal 27-28 Juni 2019. Pada penelitian ini, sebagai subjek penelitian adalah siswa kelas VIII yang berjumlah 30 orang. Sebelum melakukan penelitian, peneliti menyampaikan maksud kepada subjek tersebut tentang penelitian ini sehingga diharapkan untuk belajar terkait materi kubus dan balok. Kemudian peneliti melakukan observasi kepada 30 siswa pada saat seorang guru menjelaskan terkait materi kubus dan balok. Setelah melakukan observasi, peneliti memberikan tes tertulis kepada siswa sebanyak 5 butir soal yang sebelumnya telah divalidasi. Dari hasil jawaban subjek tersebut, peneliti melakukan wawancara kepada 8 orang siswa yang diambil dari 4 siswa dengan kemampuan pemecahan diatas rata-rata dan 4 orang siswa dengan kemampuan pemecahan masalah dibawah rata-rata.

Tabel 4. Hasil Observasi Aktivitas Siswa

\begin{tabular}{|l|c|c|}
\hline $\begin{array}{c}\text { Indikator Pemecahan } \\
\text { Masalah }\end{array}$ & L/P & $\begin{array}{c}\text { Observasi } \\
\text { Aktivitas Siswa }\end{array}$ \\
\hline \multirow{2}{*}{ Memahami Masalah } & $\mathrm{L}$ & $40 \%$ \\
\cline { 2 - 3 } Merancang Strategi & $\mathrm{P}$ & $55 \%$ \\
\hline \multirow{2}{*}{ Melakukan Perhitungan } & $\mathrm{L}$ & $28 \%$ \\
\cline { 2 - 3 } & $\mathrm{P}$ & $47 \%$ \\
\hline \multirow{2}{*}{ Mengecek Kembali Solusi } & $\mathrm{L}$ & $34 \%$ \\
\cline { 2 - 3 } & $\mathrm{P}$ & $76 \%$ \\
\cline { 2 - 3 } & $\mathrm{L}$ & $11 \%$ \\
\hline
\end{tabular}

Cartesius: Jurnal Pendidikan Matematika Vol. 3, No. 1

CProdi Pendidikan Matematika Universitas Katolik Santo Thomas 
Tabel 5. Daftar Nilai Dan Pengelompokan Kriteria Kemampuan Pemecahan Masalah

\begin{tabular}{|c|c|c|c|c|c|c|}
\hline $\begin{array}{l}\text { No. } \\
\text { Abse } \\
\text { n }\end{array}$ & $\mathbf{L} / \mathbf{P}$ & Nilai & $\begin{array}{c}\text { Kriteria } \\
\text { Kemampua } \\
\text { n }\end{array}$ & $\begin{array}{c}\text { Total } \\
\text { Sisw } \\
\text { a }\end{array}$ & $\begin{array}{l}\text { Perse } \\
\text { ntase }\end{array}$ & $\begin{array}{c}\text { Persentase } \\
\text { L/P }\end{array}$ \\
\hline 3 & $\mathrm{P}$ & 80 & \multirow{14}{*}{$\begin{array}{c}\text { Diatas Rata- } \\
\text { Rata }\end{array}$} & \multirow[t]{14}{*}{14} & \multirow[t]{14}{*}{$46.6 \%$} & \multirow{14}{*}{$\begin{aligned} \mathrm{L} & =\frac{5}{30} \times 100 \% \\
& =16,6 \% \\
\mathrm{P} & =\frac{5}{30} \times 100 \% \\
& =30 \%\end{aligned}$} \\
\hline 15 & $\mathrm{P}$ & 80 & & & & \\
\hline 5 & $\mathrm{~L}$ & 78,3 & & & & \\
\hline 18 & L & 76 & & & & \\
\hline 16 & $\mathrm{~L}$ & 70 & & & & \\
\hline 1 & $\mathrm{~L}$ & 66.6 & & & & \\
\hline 17 & $\mathrm{P}$ & 66.6 & & & & \\
\hline 2 & $\mathrm{P}$ & 65 & & & & \\
\hline 21 & $\mathrm{P}$ & 65 & & & & \\
\hline 19 & $\mathrm{~L}$ & 65 & & & & \\
\hline 23 & $\mathrm{P}$ & 60 & & & & \\
\hline 30 & $\mathrm{P}$ & 55 & & & & \\
\hline 12 & $\mathrm{P}$ & 52 & & & & \\
\hline 24 & $\mathrm{P}$ & 51,6 & & & & \\
\hline 11 & $\mathrm{~L}$ & 50 & \multirow{8}{*}{$\begin{array}{l}\text { Dibawah } \\
\text { Rata-Rata }\end{array}$} & \multirow[t]{8}{*}{16} & \multirow[t]{8}{*}{$53,3 \%$} & \multirow{8}{*}{$\begin{aligned} \mathrm{L} & =\frac{14}{30} \times 100 \% \\
& =46,6 \% \\
\mathrm{P} & =\frac{2}{30} \times 100 \% \\
& =6,6 \%\end{aligned}$} \\
\hline 25 & $\mathrm{P}$ & 25 & & & & \\
\hline 29 & $\mathrm{~L}$ & 47 & & & & \\
\hline 22 & L & 47 & & & & \\
\hline 14 & L & 46 & & & & \\
\hline 6 & $\mathrm{~L}$ & 45 & & & & \\
\hline 8 & $\mathrm{~L}$ & 45 & & & & \\
\hline 20 & $\mathrm{~L}$ & 45 & & & & \\
\hline
\end{tabular}

Cartesius: Jurnal Pendidikan Matematika Vol. 3, No. 1

CProdi Pendidikan Matematika Universitas Katolik Santo Thomas 


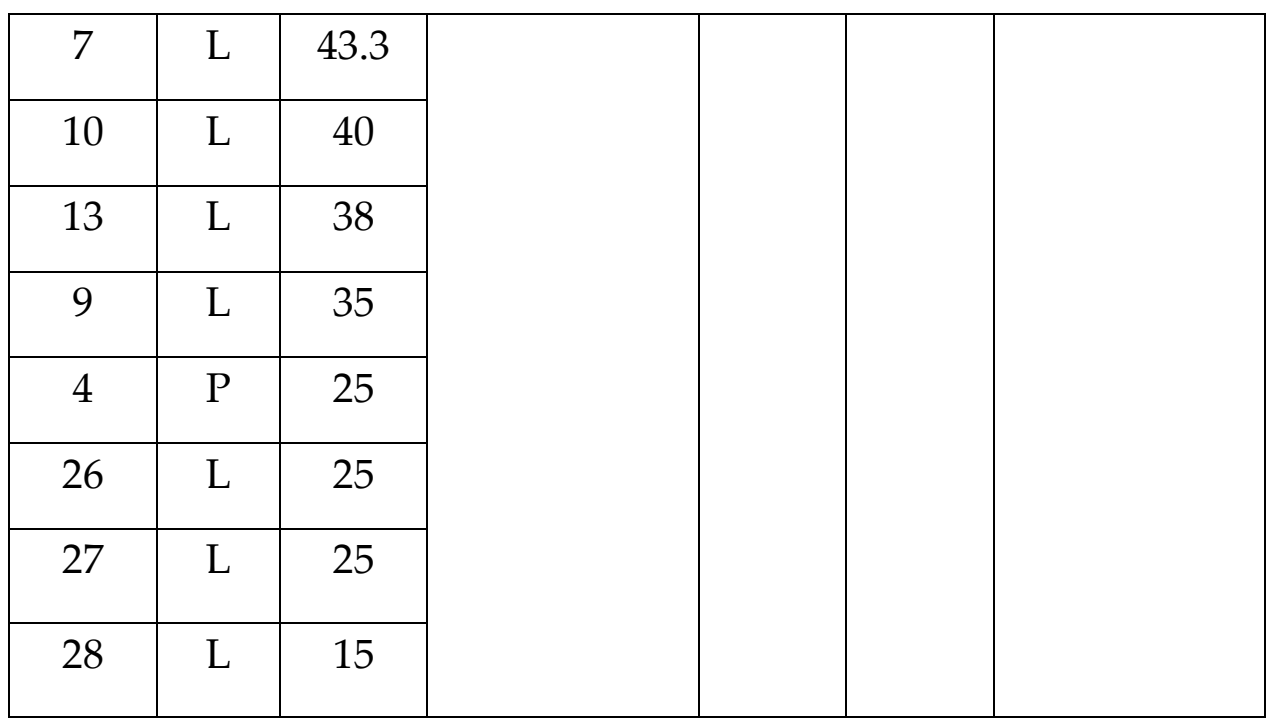

Dari hasil analisis observasi yang disajikan diatas akan dibahas lebih lanjut terkait bagaimana tingkat partisipasi siswa laki-laki maupun siswa perempuan secara keseluruhan dalam melakukan aktivitas sesuai tahapan pemecahan masalah. Berikut adalah pembahasan megenai kemampuan pemecahan masalah siswa laki-laki maupun siswa perempuan dari data observasi:

a. Tahap memahami masalah

Pada tahap memahami masalah, dari hasil observasi aktivitas menunjukan bahwa partisipasi siswa perempuan lebih unggul dibandingkan partisipasi siswa laki-laki.

b. Tahap merancang strategi pemecahan masalah

Tahap merancang strategi pemecahan masalah, dari hasil observasi menunjukan bahwa partisipasi siswa perempuan lebih unggul dibandingkan partisipasi siswa laki-laki.

c. Tahap melakukan perhitungan

Tahap melakukan perhitungan, dari hasil observasi menunjukan bahwa partisipasi siswa perempuan lebih unggul dibandingkan partisipasi siswa laki-laki.

d. Tahap mengecek kembali solusi

Tahap mengecek kembali solusi, dari hasil observasi aktivtas siswa I menunjukan bahwa partisipasi siswa perempuan lebih unggul dibandingkan siswa laki-laki.

Cartesius: Jurnal Pendidikan Matematika Vol. 3, No. 1

CProdi Pendidikan Matematika Universitas Katolik Santo Thomas 
Tes Tertulis Dilengkapi Wawancara

Dari deskripsi data tes tertulis yang dilengkapi wawancara dapat dipaparkan bagaimana kemampuan pemecahan masalah yang dimiliki oleh siswa laki-laki maupun perempuan. Berikut ini adalah pebahasan mengenai kemampuan pemecahan masalah siswa laki-aki maupun perempuan dari data tes tertulis yang dilengkapi dari data wawancara.

\section{a. Soal Nomor 1}

1. Tahap memahami masalah

a. Dua siswa perempuan dan dua siswa laki-laki mampu menyebutkan apa yang diketahui dan ditanya dengan benar.

b. Dua siswa perempuan dan satu siswa laki-laki hanya mampu menyebutkan apa yang ditanya dari soal.

c. Satu orang siswa laki-laki tidak dapat menyebutkan apa yang ditanya dan diketahui dari soal.

Hal ini menunjukan bahwa terdapat dua siswa laki-laki dan dua siswa perempuan yang mampu memahami masalah sedangkan dua siswa perempuan dan satu siswa laki-laki hanya dapat menuliskan data di ketahui dan satu orang tidak menjawab sama sekali. Sehingga terlihat bahwa siswa laki-laki dan siswa perempuan memiliki kemampuan memahami masalah yang sama pada soal nomor 1 .

2. Tahap menyusun rencana penyelesaian

a. 2 siswa laki-laki dan 2 siswa perempuan mampu menyusun rencana penyelesaian dengan benar.

b. 2 siswa laki-laki dan 2 siswa perempuan belum mampu menyusun rencana penyelesaian dengan benar.

Sehingga terlihat bahwa siswa laki-laki dan siswa perempuan memiliki kemampuan menyusun rencana penyelesaian yang sama pada soal nomor 1 .

3. Tahap melakukan perhitungan

a. 2 siswa laki-laki dan 2 siswa perempuan mampu melakukan perhitungan dengan benar.

b. 2 siswa laki-laki dan 2 siswa perempuan belum mampu melakukan perhitungan dengan benar.

Cartesius: Jurnal Pendidikan Matematika Vol. 3, No. 1

CProdi Pendidikan Matematika Universitas Katolik Santo Thomas 
Sehingga terlihat bahwa siswa laki-laki dan siswa perempuan memiliki kemampuan menyusun rencana penyelesaian yang sama pada soal nomor 1 .

4. Tahap memeriksa kembali solusi

a. 2 siswa laki-laki dan 2 siswa perempuan mampu menarik kesimpulan dari soal dengan benar.

b. 2 siswa laki-laki dan 2 siswa perempuan belum mampu menarik kesimpulan dari soal dengan benar dan tidak mencari cara lain dalam penyelesaian pada soal no. 1 .

Dari poin a dan b menunjukkan bahwa 2 siswa laki-laki dan 2 siswa perempuan mampu mengecek solusi yang diperoleh sedangkan 2 siswa laki-laki dan 2 siswa perempuan belum mampu mengecek ulang solusi yang diperoleh. Sehingga terlihat bahwa kemampuan siswa laki-laki dan perempuan dalam mengecek kembali solusi sama pada soal no.1.

\section{b. Soal Nomor 2}

1. Tahap memahami masalah

a. 2 siswa perempuan dan 3 siswa laki-laki mampu menyebutkan data diketahui dan ditanya dari soal.

b. 1 laki-laki dan 2 perempuan tidak mampu menyebutkan data diketahui dan ditanya dari soal.

Hal ini menunjukan bahwa kemampuan memahami masalah siswa laki-laki lebih unggul dari soal nomor 2

2. Tahap menyusun rencana penyelesaian

a. 2 siswa perempuan dan 3 siswa laki-laki mampu menyusun rencana penyelesaian denagn benar.

b. 2 siswa perempuan dan 1 siswa laki-laki tidak mampu menyusun rencana penyelesaian denagn benar.

Hal ini menunjukan bahwa kemampuan menyusun rencana penyelesaian siswa laki-laki lebih unggul dari soal nomor 2

3. Tahap melakukan perhitungan

a. 2 siswa perempuan dan 2 siswa laki-laki mampu melakukan perhitungan dengan benar.

Cartesius: Jurnal Pendidikan Matematika Vol. 3, No. 1

CProdi Pendidikan Matematika Universitas Katolik Santo Thomas 
b. 2 siswa perempuan dan 2 siswa laki-laki tidak mampu melakukan perhitungan dengan benar.

Sehingga terlihat bahwa kemampuan siswa laki-laki dan perempuan melakukan perhitungan sama pada soal no.2

4. Tahap memeriksa kembali solusi

a. 1 siswa perempuan dapat menarik kesimpulan serta mengecek solusi yang diperoleh dengan benar.

b. 3 siswa perempuan dan 4 siswa laki-laki tidak dapat menarik kesimpulan serta mengecek solusi yang diperoleh dengan benar.

Sehingga terlihat bahwa kemampuan mengecek ulang solusi yang di peroleh siswa perempuan lebih unggul dibandingkan siswa laki-laki

\section{c. Soal nomor 3}

1. Tahap memahami masalah

a. 3 siswa perempuan dan 4 siswa laki-laki mampu menyebutkan apa yang diketahui dan ditanya dengan benar .

b. 1 siswa perempuan tidak mampu menyebutkan apa yang diketahui dan ditanya dengan benar .

Sehingga terlihat bahwa siswa laki-laki lebih unggul dari pada siswa perempuan memiliki kemampuan memahami masalah yang sama pada soal nomor 3.

2. Tahap menyusun rencana penyelesaian

a. 2 siswa laki-laki dan 2 siswa perempuan mampu menyusun rencana penyelesaian dengan benar.

b. 2 siswa laki-laki dan 2 siswa perempuan tidak mampu menyusun rencana penyelesaian dengan benar.

Sehingga terlihat bahwa siswa laki-laki dan siswa perempuan memiliki kemampuan menyusun rencana penyelesaian yang sama pada soal nomor 3.

3. Tahap melakukan perhitungan

a. 2 siswa perempuan dan 2 siswa laki-laki mampu melakukan perhitungan dengan benar.

Cartesius: Jurnal Pendidikan Matematika Vol. 3, No. 1

CProdi Pendidikan Matematika Universitas Katolik Santo Thomas 
b. 2 siswa perempuan dan 2 siswa laki-laki tidak mampu melakukan perhitungan dengan benar

Sehingga terlihat bahwa kemampuan siswa laki-laki dan perempuan dalam melakukan perhitungan sama pada soal no.3

4. Tahap memeriksa kembali solusi

a. 2 siswa perempuan dan 2 siswa laki-laki dapat menarik kesimpulan serta mengecek solusi yang diperoleh dengan benar.

b. 2 siswa perempuan dan 2 siswa laki-laki tidak dapat menarik kesimpulan serta mengecek solusi yang diperoleh dengan benar.

\section{d. Soal nomor 4}

1. Tahap memahami masalah

a. 3 siswa perempuan dan 2 siswa laki-laki mampu menyebutkan data diketahui dan ditanya dari soal.

b. 2 laki-laki dan 1 perempuan tidak mampu menyebutkan data diketahui dan ditanya dari soal.

Hal ini menunjukan bahwa kemampuan memahami masalah siswa perempuan lebih unggul dibanding laki-laki untuk soal nomor 4

2. Tahap menyusun rencana penyelesaian

a. 2 siswa laki-laki dan 2 siswa perempuan mampu menyusun rencana penyelesaian dengan benar.

b. 2 siswa laki-laki dan 2 siswa perempuan tidak mampu menyusun rencana penyelesaian dengan benar.

Sehingga terlihat bahwa siswa laki-laki dan siswa perempuan memiliki kemampuan menyusun rencana penyelesaian yang sama pada soal nomor 4 .

3. Tahap melakukan perhitungan

a. siswa perempuan dan 2 siswa laki-laki mampu melakukan perhitungan dengan benar

b. 2 siswa perempuan dan 2 siswa laki-laki tidak mampu melakukan perhitungan dengan benar

Cartesius: Jurnal Pendidikan Matematika Vol. 3, No. 1

CProdi Pendidikan Matematika Universitas Katolik Santo Thomas 
Sehingga terlihat bahwa kemampuan siswa laki-laki dan perempuan dalam melakukan perhitungan sama pada soal no.4

4. Tahap memeriksa kembali solusi

a. 2 siswa perempuan dan 2 siswa laki-laki dapat menarik kesimpulan serta mengecek solusi yang diperoleh dengan benar.

b. 2 siswa perempuan dan 2 siswa laki-laki tidak dapat menarik kesimpulan serta mengecek solusi yang diperoleh dengan benar

Sehingga terlihat bahwa siswa laki-laki dan siswa perempuan sama mengecek kembali solusi pada soal no. 4 .

\section{e. Soal nomor 5}

1. Tahap memahami masalah

a. 3 siswa laki-laki dan 4 siswa perempuan mampu menyebutkan data diketahui dan ditanya dari soal.

b. 1 laki-laki tidak mampu menyebutkan data diketahui dan ditanya dari soal.

Hal ini menunjukan bahwa kemampuan memahami masalah siswa perempuan lebih unggul dibanding laki-laki untuk soal nomor 5.

2. Untuk tahap menyusun rencana penyelesaian, melakukan perhitugan dan memeriksa kembali solusi siswa laki-laki dan siswa perempuan tidak dapat menjawab untuk soal nomor 5 .

Dari pembahasan tes tertulis dilengkapi wawancara diatas, akan dicek kembalitotal siswa laki-laki maupun siswa perempuan dalam tiap tahap pemecahan masalah yang disajikan pada tabel berikut:

Tabel 6. Banyak Siswa Dilihat dari Tahap Pemecahan Masalah

\begin{tabular}{ccccccc}
\hline No. & $\begin{array}{c}\text { Tahap Pemecahan } \\
\text { Masalah }\end{array}$ & Soal 1 & Soal 2 & Soal 3 & Soal 4 & Soal 5 \\
\hline
\end{tabular}

1. Memahami masalah

\begin{tabular}{lcccccc}
\hline $\begin{array}{l}\text { A. Mampu memahami } \\
\text { masalah }\end{array}$ & $3 \mathrm{~L}$ & $3 \mathrm{~L}$ & $4 \mathrm{~L}$ & $2 \mathrm{~L}$ & $3 \mathrm{~L}$ \\
\cline { 2 - 6 } & $4 \mathrm{P}$ & $2 \mathrm{P}$ & $3 \mathrm{P}$ & $3 \mathrm{P}$ & $4 \mathrm{P}$
\end{tabular}

Cartesius: Jurnal Pendidikan Matematika Vol. 3, No. 1

CProdi Pendidikan Matematika Universitas Katolik Santo Thomas 


\begin{tabular}{|c|c|c|c|c|c|c|}
\hline & \multirow{2}{*}{$\begin{array}{l}\text { B. Belum mampu } \\
\text { memahami masalah }\end{array}$} & $1 \mathrm{~L}$ & $1 \mathrm{~L}$ & $1 \mathrm{P}$ & $2 \mathrm{~L}$ & $1 \mathrm{~L}$ \\
\hline & & - & $2 \mathrm{P}$ & - & $1 \mathrm{P}$ & - \\
\hline \multirow[t]{5}{*}{2.} & $\begin{array}{l}\text { Menyusun rencana } \\
\text { penyelesaian }\end{array}$ & & & & & \\
\hline & \multirow{2}{*}{$\begin{array}{l}\text { A. Menyusun rencana } \\
\text { penyelesaian }\end{array}$} & $2 \mathrm{~L}$ & $2 \mathrm{~L}$ & $2 \mathrm{~L}$ & $2 \mathrm{~L}$ & - \\
\hline & & $2 \mathrm{P}$ & $3 \mathrm{P}$ & $2 \mathrm{P}$ & $2 \mathrm{P}$ & - \\
\hline & \multirow{2}{*}{$\begin{array}{l}\text { B. Belum menyusun } \\
\text { rencana }\end{array}$} & $2 \mathrm{~L}$ & $1 \mathrm{~L}$ & $2 \mathrm{~L}$ & $2 \mathrm{~L}$ & - \\
\hline & & $2 \mathrm{P}$ & $2 \mathrm{P}$ & $2 \mathrm{P}$ & $2 \mathrm{P}$ & - \\
\hline \multirow[t]{5}{*}{3.} & $\begin{array}{l}\text { Melakukan } \\
\text { perhitungan }\end{array}$ & & & & & \\
\hline & \multirow{2}{*}{$\begin{array}{l}\text { A. Melakukan } \\
\text { perhitungan }\end{array}$} & $2 \mathrm{~L}$ & $2 \mathrm{~L}$ & $2 \mathrm{~L}$ & $2 \mathrm{~L}$ & - \\
\hline & & $2 \mathrm{P}$ & $2 \mathrm{P}$ & $2 \mathrm{P}$ & $2 \mathrm{P}$ & - \\
\hline & \multirow{2}{*}{$\begin{array}{l}\text { B. Belum melakukan } \\
\text { perhitungan }\end{array}$} & $2 \mathrm{~L}$ & $2 \mathrm{~L}$ & $2 \mathrm{~L}$ & $2 \mathrm{~L}$ & - \\
\hline & & $2 \mathrm{P}$ & $2 \mathrm{P}$ & $2 \mathrm{P}$ & $2 \mathrm{P}$ & - \\
\hline \multirow[t]{5}{*}{4.} & $\begin{array}{l}\text { Memeriksa kembali } \\
\text { solusi }\end{array}$ & & & & & \\
\hline & \multirow{2}{*}{$\begin{array}{l}\text { A. Memeriksa kembali } \\
\text { solusi }\end{array}$} & $2 \mathrm{~L}$ & - & $2 \mathrm{~L}$ & $2 \mathrm{~L}$ & - \\
\hline & & $2 \mathrm{P}$ & $1 \mathrm{P}$ & $2 \mathrm{P}$ & $2 \mathrm{P}$ & - \\
\hline & \multirow{2}{*}{$\begin{array}{l}\text { B. Belum memeriksa } \\
\text { kembali solusi }\end{array}$} & $2 \mathrm{~L}$ & $4 \mathrm{~L}$ & $2 \mathrm{~L}$ & $2 \mathrm{~L}$ & - \\
\hline & & $2 \mathrm{P}$ & $3 \mathrm{P}$ & $2 \mathrm{P}$ & $2 \mathrm{P}$ & - \\
\hline
\end{tabular}

Keterangan :
L: Laki-Laki
P: Perempuan

Cartesius: Jurnal Pendidikan Matematika Vol. 3, No. 1

CProdi Pendidikan Matematika Universitas Katolik Santo Thomas 
Dari hasil pembahasan yang dirinci dari tabel 6 maka hasil yang di peroleh bahwa kemampuan siswa perempuan dalam memahami masalah lebih unggul dibandingkan siswa laki-laki. Selain itu teori lain menurut Krutetski (Nafi'an, dkk., 2011: 573) mengatakan bahwa kemampuan matematika dan mekanik siswa laki-laki lebih baik daripada siswa perempuan. Namun, pada kenyataanya diperoleh bahwa kemampuan matematika siswa perempuan lebih unggul dibandingkan siswa laki-laki. Hal ini juga didasai oleh teori yang mengatakan bahwa perempuan lebih unggul dalam ketepatan, ketelitian, kecermatan,dan keseksamaan berpikir. Sehingga, dalam menyelesaikan matematika siswa perempuan lebih baik dalam menentuakan rumus apa saja yang dibutuhkan dalam menyelesaikan soal yang diberikan.

\section{KESIMPULAN}

Berdasarkan hasil penelitian yang telah diuraikan oleh peneliti, maka dapat disimpulkan bahwa kemampuan siswa perempuan lebih unggul di bandingkan siswa laki-laki dalam pemecahan masalah berbentuk soal konstektual pada pokok bahasan kubus dan balok ditinjau dari gender di kelas VIII SMP Darma Wanita Pertiwi, dijelaskan pada point dibawah ini:

a. Siswa perempuan lebih sedikit menemukan kesulitan dalam memahami soal kontekstual yang diberikan. Sehingga lebih mampu menerjemahkan soal kedalam unsur-unsur diketahui dan ditanya maupun kedalam bentuk matematika secara lengkap dan benar. Hal ini menunjukan bahwa siswa perempuan memiliki kemampuan memahami soal yang lebih unggul dibandingkan siswa laki-laki.

b. Siswa perempuan lebih mampu dalam memilih ataupun menyusun rumus apa saja yang diperlukan dalam menyelesaikan soal kontekstual yang diberikan. Hal ini dikarenakan siswa perempuan lebih baik dalam menghafal dan memahami rumus-rumus matematika.

c. Siswa laki-laki lebih teliti dan cermat melakukan perhitungan dalam menyelesaikan soal kontekstual yang diberikan. Selain itu, siswa lakilaki juga lebih mampu menjelaskan setiap langkah perhitungan yang dilakukan. Hal ini menunjukkan bahwa siswa laki-laki memiliki kemampuan melakukan perhitungan yang lebih unggul dari siswa perempuan.

Cartesius: Jurnal Pendidikan Matematika Vol. 3, No. 1

CProdi Pendidikan Matematika Universitas Katolik Santo Thomas 
d. Siswa perempuan lebih mampu dalam mengecek ulang solusi yang diperoleh dan menarik kesimpulan sesuai dengan apa yang ditanya di soal. Hal ini menunjukkan bahwa kemampuan siswa perempuan dalam mengecek kembali solusi yang diperoleh dari soal kontekstual yang diberikan lebih unggul dibandingkan siswa laki-laki.

Berdasarkan hasil penilitian dan pembahasan yang telah diuraikan, maka dapat dikemukakan saran sebagai berikut:

a. Disarankan guru lebih memperhatikan partisipasi siswa laki-laki dibandingkan siswa perempuan agar seluruh siswa mampu secara aktif mengikuti pembelajaran yang berlangsung dengan baik.

b. Disarankan guru membiasakan siswa menyelesaikan soal-soal yang diberikan menggunakan aturan-aturan pengerjaan soal yang benar. Dimulai dari menuliskan data diketahui dan ditanya, menyusun rencana penyelesaian dengan menulis rumus sesuai apa yang ditanya dari soal, membuat perhitungan dan mengecek kembali solusi atau menarik kesimpulan dari jawaban yang dibuat.

c. Menyarankan untuk setiap jam pembelajaran berlangsung siswa lakilaki disuruh duduk bangku depan agar selalu bisa dipantau agar partisipasi siswa laki-laki dan perempuan bisa memajukan berlangsungnya pembelajaran diruangan kelas.

\section{UCAPAN TERIMAKASIH}

Penulis menyampaikan terimakasih kepada Ibu Ribka Kariani Br. Sembiring, S.Si., M.Pd. sebagai Dosen Pembimbing 1 dan Ibu Imelda Sihombing, S.Pd., M.Pd. sebagai Dosen Pembimbing 2 yang telah mengarahkan dan membimbing penulis mulai dari awal penelitian hingga berakhirnya penelitian sehingga penulis dapat menuliskan artikel ini yang merupakan bagian dari hasil penelitian penulis. Penulis juga menyampaikan terimakasih kepada Kepala Program Studi Pendidikan Matematika, Dekan, dan Rektor Universitas Katolik Santo Thomas atas dukungan yang diberikan kepada penulis.

Cartesius: Jurnal Pendidikan Matematika Vol. 3, No. 1

CProdi Pendidikan Matematika Universitas Katolik Santo Thomas 


\section{DAFTAR PUSTAKA}

[1] Amir, Zubaidah. 2013. Perspektif Gender dalam Pembelajaran Matematika. Bandung: jurnal.

[2] Anggraeni, dkk. 2018. Kemampuan Pemecahan Masalah Matematika Siswa SMP Pada Materi Lingkaran Berbentuk Soal Kontekstual Ditinjau Dari Gender. Jakarta. Jurnal.

[3] Farichah, dkk., 2018. Kemampuan Pemecahan Masalah Matematika Peserta Didik Melalui Model Pembelajaran Kooperatif Team Assisted Individualization (TAI) di Kelas VII-A SMPN 1 Kebomas. Jurnal.

[4] Francisco, Stela. 2017. Analisis Kemapuan Pemecahan Masalah Pada Materi Kubus dan Balok Berbentuk Soal Kontekstual Ditinjau Dari Gender Siswa Kelas Viii Smp Asisi MedanTahun Pelajaran 2018/2019. Yogyakarta. Skripsi.

[5] Hendriana, dkk., 2017. Penilaian Pembelajaran Matematika. Bandung: Revika Aditama.

[6] Ilman, dkk. 2011. Kemampuan Siswa dalam Menyelesakan Soal Cerita Ditinjau dari Gender di Sekolah Dasar. Yogyakarta. Jurnal.

[7] Nafi'an, dkk., 2011. Kemampuan Siswa Dalam Menyelesaikan Soal Cerita Ditinjau dari Gender di Sekolah Dasar. Yogyakarta: Jurnal.

[8] Panjaitan, dkk., 2017. Upaya Meningkatkan Kemampuan Pemecahan Masalah Matematika Siswa dengan Menggunakan Model Pembelajaran Problem Based Learning di Kelas X SMA. Jurnal.

[9] Sadirman. 2010. Interaksi dan Motivasi Belajar Mengajar. Jakarta: Rajawali Pers.

[10] Saragih, Sahat, dkk., Peningkatan Kemampuan Pemecahan Masalah dan Komunikasi Matematika Melalui Pendekatan Matematika Realistik Pada Siswa SMP Kelas VII Langsa. Paradikma Jurnal Pendidika Matematika. Vol. 6, 2013.

[11] Shodikin, Ali. 2015. Peningkatan Kemampuan Pemecahan Masalah Siswa Melalui Strategi Abduktif-Deduktif pada Pembelajaran Matematika. Jurnal.

[12] Sukardi.2013. Metodologi Penelitian Pendidikan. Jakarta : Bumi Aksara.

[13] Susanto, Ahmad. 2014. Teori Belajar dan Pembelajaran di Sekolah Dasar. Jakarta: Kencana.

Cartesius: Jurnal Pendidikan Matematika Vol. 3, No. 1

CProdi Pendidikan Matematika Universitas Katolik Santo Thomas 
[14] Trianto. 2009. Mendesain Model Pembelajaran Inovatif-Progresif. Jakarta: Kencana Prenada Media Group.

[15] Widiawati, dkk., 2011. Kemampuan Berpikir Reflektif Siswa Dalam Memecahkan Masalah Matematika Pada Materi Sistem Persamaan Linear Dua Variabel (SPLDV) Berdasarkan Gender Kelas VIII di MTS Negeri Tanjunganom. Jurnal. 